\author{
Justyna Adamus-Kowalska \\ Zakład Zarządzania Informacją \\ Instytut Bibliotekoznawstwa i Informacji Naukowej \\ Uniwersytet Śląski w Katowicach \\ e-mail: justyna.adamus@us.edu.pl \\ (D) https://orcid.org/0000-0002-8245-7631
}

\title{
Polityka państwa polskiego w zakresie postępowania z dokumentacją elektroniczną oraz wdrażanie systemu elektronicznego zarządzania dokumentacją (EZD) w kontekście informatyzacji
}

\begin{abstract}
Abstrakt: Zarządzanie dokumentacją elektroniczną to jedno z istotnych zadań współczesnej administracji publicznej. W artykule wskazano na konieczność stosowania przepisów prawnych z zakresu informatyzacji oraz instrukcji kancelaryjnej określającej sposób prowadzenia dokumentacji urzędowej w podmiotach publicznych. Opisano narzędzia teleinformatyczne w postaci systemu EZD, by pokazać, jak kształtowany jest obecnie narodowy zasób archiwalny. W celu usprawnienia procesu informatyzacji administracji publicznej przyjmuje się programy rządowe, np. omówiony w artykule Program Zintegrowanej Informatyzacji Państwa. Zaprezentowane badania dowodzą, że pełna realizacja elektronicznych usług administracji publicznej wymaga ujednolicenia zasad funkcjonowania systemu kancelaryjnego, w tym przyjęcia odpowiednich założeń i wdrożenia systemu EZD RP oraz szerszego wykorzystania ogólnopolskiej platformy komunikacji z administracją publiczną (ePUAP).
\end{abstract}

Słowa kluczowe: Administracja. Dokument elektroniczny. Informatyzacja. Kancelaria. System EZD 


\section{Wprowadzenie}

Postępowanie $\mathrm{z}$ dokumentacją $\mathrm{w}$ urzędach administracji publicznej polega na stosowaniu odpowiednich standardów i przepisów prawnych. Najważniejsze w tym kontekście jest przedstawienie przepisów z zakresu administracji publicznej, które mają bezpośredni wpływ na kształtowanie narastającego zasobu archiwalnego ${ }^{1}$, a tym samym warunkują to, jak w przyszłości organizowana będzie informacja archiwalna. Ogólne ramy rozwoju informatyzacji $\mathrm{w}$ państwie tworzone są poprzez przepisy prawne - w ten sposób wprowadzone zostały rozwiązania obowiązujące w polskich urzędach. Przede wszystkim obowiązkowe jest stosowanie odpowiednich narzędzi teleinformatycznych w prowadzeniu spraw urzędowych. Polityka państwa znajduje swoje odzwierciedlenie w programach rządowych, stąd też istotne jest wskazanie na zapisy obejmujące informatyzację i elektroniczne zarządzanie dokumentacją (EZD).

Informacja archiwalna stanowi jeden $\mathrm{z}$ istotnych typów specjalistycznej informacji naukowej. Informacja o dokumentacji gromadzonej $\mathrm{w}$ archiwach to rodzaj informacji naukowej mającej umożliwiać prowadzenie badań nad różnymi aspektami funkcjonowania państwa i społeczeństwa. Równie istotna jest wartość dowodowa tejże informacji. W niniejszym artykule skupiono się na informacji bieżącej, powstającej współcześnie w administracji.

Rozwój informacji archiwalnej uzależniony jest od zmian, jakie dokonują się na tzw. przedpolu archiwalnym, czyli w obszarze funkcjonowania kancelarii. W szerszym ujęciu jest to element rozwoju społeczno-gospodarczego państwa, w zakresie którego na uwagę zasługuje w pierwszej kolejności system kancelaryjny, a następnie proces informatyzacji państwa.

System elektronicznego zarządzania dokumentacją (dalej: EZD) ${ }^{2}$ powstał w efekcie rozwoju technologii informacyjnych i komunikacyjnych. Najistotniejszą cechą tego systemu jest silne umocowanie prawne wszystkich zasad i narzędzi, które mają gwarantować zachowanie dokumentów w toku prowadzenia i załatwiania spraw urzędowych.

${ }^{1}$ Według Polskiego stownika archiwalnego narastający zasób archiwalny to „materiały archiwalne wytwarzane i gromadzone w wyniku aktualnej działalności twórców zespołów" (Maciejewska, 1974, s. 55).

${ }^{2}$ System EZD to system teleinformatyczny do elektronicznego zarządzania dokumentacją, umożliwiający wykonywanie w nim czynności kancelaryjnych, dokumentowanie przebiegu załatwiania spraw oraz gromadzenie i tworzenie dokumentów elektronicznych (Rozporządzenie, 2011, §2, pkt 13). 
W tym kontekście rozpatrzenia wymagają następujące problemy badawcze: $w$ jaki sposób odbywa się proces informatyzacji w administracji publicznej przy wykorzystaniu narzędzi teleinformatycznych w postaci systemu EZD; jakie są przepisy prawne regulujące postępowanie z dokumentacją; jak powstaje dokument elektroniczny i jakie otrzymuje metadane; czym jest dokument $\mathrm{w}$ postaci elektronicznej oraz jak są przetwarzane informacje w nim zawarte. Konieczne jest też zwrócenie uwagi na możliwości zarządzania zmianą w procesie wdrażania EZD. Badania mają na celu wskazanie kierunków rozwoju systemu EZD oraz nadzoru archiwalnego, aby narodowy zasób archiwalny będący efektem działania systemu EZD był kompletny, wiarygodny, trwały, aby informacje i dane zgromadzone przy użyciu tego systemu były użyteczne i zgodne z najlepszą praktyką zarządzania informacją.

Metody i narzędzia badawcze wykorzystane w przedstawionej pracy to analiza literatury, badania prowadzone przez Ministra Cyfryzacji w zakresie informatyzacji administracji publicznej, analiza dokumentów programowych, w tym w szczególności Programu Zintegrowanej Informatyzacji Państwa (wersja z września 2016 r.) jako strategicznego dokumentu opisującego działania rządu zmierzające do dostarczenia społeczeństwu wysokiej jakości elektronicznych usług publicznych.

\section{System kancelaryjny}

W celu omówienia systemu elektronicznego zarządzania dokumentacją (EZD) niezbędne jest wskazanie, czym jest kancelaria i jak postępuje się z dokumentacją w systemie kancelaryjnym. W Polskim słowniku archiwalnym kancelaria została zdefiniowana jako „komórka organizacyjna lub zespół komórek organizacyjnych w urzędzie (instytucji) zajmujących się przyjmowaniem, rejestracją i rozdzielaniem pism wpływających, przygotowywaniem, rejestracją i wysyłaniem pism wychodzących oraz przechowywaniem akt danego urzędu" (Maciejewska, 1974, s. 40). Z kolei system kancelaryjny to „sposób rejestracji, obiegu i układu akt powstających w toku bieżącej działalności twórcy zespołu" (Maciejewska, 1974, s. 80). Halina Robótka wskazała, że funkcje kancelaryjne zawsze związane są z utrwaleniem informacji, jaka wpływa do aktotwórcy oraz znajduje się wewnątrz obiegu (Robótka, 2010, s. 15). Informacja taka musi być w odpowiedni sposób utrwalana i gromadzona oraz udostępniana. Niemniej w rozwoju pracy biurowej i administracyjnej pojęcie kancelarii i pracy kancelaryjnej coraz częściej zastępuje się pojęciem zarządzania dokumentacją. 
Podstawowym normatywem z zakresu zarządzania dokumentacją jest instrukcja kancelaryjna, określana jako „przepisy normujące zasady i tryb wykonywania czynności kancelaryjnych oraz postępowania z aktami do momentu przekazania ich do archiwum" (Maciejewska, 1974, s. 37). Samo pojęcie czynności kancelaryjnych obejmuje czynności związane z przyjmowaniem pism przychodzących, ich rejestrowaniem i nadawaniem pismom i sprawom znaków (sygnatur) kancelaryjnych, rozdziałem pism między referentów, łączeniem pism w sprawy, przygotowaniem pism wychodzących, rejestrowaniem i wysyłką pism, a także przechowywaniem akt spraw zakończonych (Robótka, 2010, s. 17).

W niniejszym artykule omawiany jest system kancelaryjny dla podmiotów wymienionych w art. 1.1 Rozporządzenia Prezesa Rady Ministrów z dnia 18 stycznia 2011 r. w sprawie instrukcji kancelaryjnej, jednolitych rzeczowych wykazów akt oraz instrukcji w sprawie organizacji i zakresu działania archiwów zakładowych (Dz. U. 2011, nr 14, poz. 67). Podmioty te stanowią organy gmin i związki międzygminne, organy powiatu, organy samorządu województwa i organy zespolonej administracji rządowej w województwie, a także urzędy obsługujące te organy. System kancelaryjny wskazany dla ww. podmiotów to system bezdziennikowy, w którym podstawą rejestracji i gromadzenia dokumentacji jest rejestracja spraw - wskazuje na to $\S 3 \mathrm{ww}$. rozporządzenia. System ten jest oparty na wykazie akt (Rozporzadzenie, 2011, załącznik nr 1, s. 5). Wykaz akt stanowi załącznik do instrukcji kancelaryjnej i jest to wykaz haseł rzeczowych oznaczonych symbolami klasyfikacyjnymi oraz kwalifikacją archiwalną (Rozporzadzenie, 2011, załącznik nr 2-5, s. 5). Wykaz akt wyraża rzeczową klasyfikację akt twórcy zespołu (Maciejewska, 1974, s. 88). Istotne jest wskazanie przez kierownika podmiotu, jaki system kancelaryjny stosuje się w urzędzie: tradycyjny czy EZD. Postępowanie z dokumentacją obejmuje wykonywanie czynności kancelaryjnych zgodnie z zapisami instrukcji kancelaryjnej zarówno w systemie EZD, jak i w systemie tradycyjnym.

\section{System EZD}

System elektronicznego zarządzania dokumentacją (EZD) jest narzędziem stosowanym w procesie informatyzacji ${ }^{3}$. To system teleinformatyczny, który warunkuje funkcjonowanie elektronicznej administracji

${ }^{3}$ Podstawę dla procesu informatyzacji w Polsce stanowi Ustawa z dnia 17 lutego 2005 r. o informatyzacji działalności podmiotów realizujących zadania publiczne (Dz.U. 2005, nr 64, poz. 565). 
w Polsce. Produktem systemu EZD jest dokument elektroniczny ${ }^{4}$. Praca $\mathrm{w}$ tym systemie polega na odpowiednim postępowaniu $\mathrm{z}$ dokumentacją, zmierzającym do tego, aby cały przebieg załatwiania spraw znajdował swoje odwzorowanie w systemie teleinformatycznym. W obiegu elektronicznym znajdują się wszystkie dokumenty wpływające i wychodzące, a także dokumentacja będąca elementem sprawy. Oryginał papierowy otrzymuje przy tym odwzorowanie cyfrowe i również musi zostać zachowany dla celów dowodowych. Podstawowym narzędziem pracy $\mathrm{w}$ systemie EZD jest odpowiednio zaprojektowany system teleinformatyczny, służący do rejestracji i obiegu dokumentów oraz ich gromadzenia w postaci elektronicznych akt spraw, a następnie ich archiwizacji. W systemie tym prowadzone są wszystkie czynności kancelaryjne, w szczególności rejestr przesyłek wpływających i wychodzących oraz spisy spraw, dekretacja, a także akceptacja poprzez podpisanie dokumentów elektronicznych odpowiednim podpisem elektronicznym. Dokonywane są rejestry lub ewidencje, z wyłączeniem rejestrów lub ewidencji prowadzonych w przeznaczonych do załatwiania określonych rodzajów spraw systemach teleinformatycznych innych niż EZD. Ponadto gromadzi się wszelkie dokumenty elektroniczne mające znaczenie dla udokumentowania przebiegu załatwiania i rozstrzygania tych spraw (Rozporzadzenie, 2011, załącznik nr 1, art. 10).

$\mathrm{Na}$ podstawie ww. instrukcji kancelaryjnej przesyłki wpływające otrzymują metadane zgodnie z zestawem zawartym w części A załącznika nr 1 do instrukcji kancelaryjnej (Rozporzadzenie, 2011, załącznik nr 1, art. 13.7).

Do systemu EZD włącza się także przesyłki, które wpływają do urzędu w formie papierowej - wykonuje się pełne odwzorowanie cyfrowe wszystkich stron wraz z załącznikami i ewentualnie kopertą. Nie dotyczy to przesyłek, których nie skanuje się ze względu na:

- rozmiar strony (np. A3 i większe);

- dużą liczbę stron;

- treść, formę lub postać (Rozporzadzenie, 2011, załącznik nr 1, art. 17.4).

W celu zachowania oryginalnych przesyłek na nośnikach papierowych tworzy się tzw. składy chronologiczne. Ich liczbę i rodzaje określają podmioty publiczne w odrębnych przepisach wewnętrznych. Problem, jaki się z tym wiąże, to przede wszystkim brak możliwości selekcji dokumentów gromadzonych w składach. Narastanie dokumentacji polega na ich chronologicznym dołączaniu do kolejnych pudeł w składach, bez

${ }^{4}$ Dokument elektroniczny jest to „stanowiący odrębną całość znaczeniową zbiór danych uporządkowanych $\mathrm{w}$ określonej strukturze wewnętrznej i zapisany na informatycznym nośniku danych" (Ustawa, 2005, art. 3). 
nadawania im kategorii archiwalnych. W tradycyjnym systemie kancelaryjnym akta papierowe otrzymują swoje miejsce $\mathrm{w}$ teczkach aktowych tworzonych zgodnie z kategorią archiwalną. Następnie wydzielane są teczki do brakowania. W przypadku systemu EZD i dokumentacji w składach chronologicznych nie jest możliwe szybkie wydzielenie dokumentów podlegających brakowaniu.

\section{Proces informatyzacji}

Przepisy z zakresu informatyzacji zostały zawarte w Ustawie $z$ dnia 17 lutego 2005 r. o informatyzacji działalności podmiotów realizujacych zadania publiczne (Dz. U. 2005, nr 64, poz. 565). W ustawie określono minimalne wymagania dla systemów teleinformatycznych używanych do realizacji zadań publicznych oraz dla rejestrów publicznych i wymiany informacji w postaci elektronicznej z podmiotami publicznymi. Ustalono także Krajowe Ramy Interoperacyjności systemów teleinformatycznych w sposób gwarantujący neutralność technologiczną i jawność używanych standardów i specyfikacji (Ustawa, 2005, art. 1). Przyjęcie jednolitej polityki $\mathrm{w}$ zakresie informatyzacji ma na celu usprawnienie dotychczasowego procesu, który charakteryzował się rozwiązaniami „wyspowymi”. Takie cząstkowe, niejednokrotnie resortowe czy też dziedzinowe podejście odpowiadało zapotrzebowaniu poszczególnych sektorów administracji publicznej, jednak nie zapewniało dostatecznej interoperacyjności systemów, co mogło mieć negatywny wpływ na realizację e-usług publicznych. Ministerstwo Cyfryzacji przygotowało Program Zintegrowanej Informatyzacji Państwa. Wersję zaktualizowaną, wzbogacony o Plan Działań Ministra Cyfryzacji (Ministerstwo Cyfryzacji, 2016). Ten dokument programowy ma umożliwić realizację następujących celów:

- rozwój społeczno-gospodarczy poprzez zapewnienie obywatelom, w tym przedsiębiorcom, efektywnych e-usług publicznych. Usługi mają być świadczone na wysokim poziomie i dostarczane przy wykorzystaniu nowoczesnych rozwiązań informatycznych wspierających logiczny i spójny system informacyjny państwa, zbudowany i utrzymywany przy współpracy wszystkich resortów;

- przejście od administrowania do zarządzania rozwojem, m.in. poprzez wprowadzenie spójnej strategii zarządzania informacją oraz jednolitych zasad i standardów budowy i eksploatacji rozwiązań IT w elektronicznej administracji, ponadto zwiększenie zarówno podaży wysokiej jakości e-usług publicznych w Polsce, jak i poziomu ich 
wykorzystania, mierzonego odsetkiem obywateli i przedsiębiorców (cel strategiczny);

- zwiększenie liczby obywateli korzystających z internetu w relacjach $\mathrm{z}$ administracją publiczną, zgodnie z celami strategii Sprawne Państwo;

- stworzenie spójnego, logicznego i sprawnego systemu informacyjnego państwa, zapewniającego przejrzystość funkcjonowania administracji, dostarczanie na poziomie wewnątrzkrajowym i europejskim usług kluczowych dla obywateli i przedsiębiorców w sposób efektywny kosztowo i jakościowo oraz zapewnienie interoperacyjności (cel operacyjny);

- zwiększenie udziału obywateli w Jednolitym Rynku Cyfrowym poprzez stworzenie spójnego systemu informacyjnego państwa, dostarczającego e-usługi na poziomie krajowym i europejskim w sposób najbardziej efektywny;

- budowanie większego zaufania do rynku cyfrowego, na co bez wątpienia wpływa zapewnienie należytej ochrony danych osobowych (Ministerstwo Cyfryzacji, 2016, s. 19).

\section{Diagnoza wdrożenia systemu EZD}

Stopień informatyzacji i wdrożenia EZD można badać m.in. poprzez wpływ dokumentacji elektronicznej na elektroniczną skrzynkę podawczą (ESP). Według badań prowadzonych przez Ministerstwo Cyfryzacji w Polsce poziom wykorzystania dokumentów elektronicznych jest dosyć niski - w 2014 r. wynosił on 11\% w stosunku do całości dokumentacji (Ministerstwo, 2014, s. 15). Liczba dokumentów wysyłanych za pomocą ESP z urzędów w pierwszej połowie 2014 r. stanowiła 9\% całości dokumentacji. Podstawowe bariery utrudniające rezygnację $\mathrm{z}$ dokumentacji papierowej w kontaktach pomiędzy urzędami to: traktowanie postaci elektronicznej dokumentów jako nierównoważnej papierowej (61\% urzędów), przyzwyczajenie (46\% urzędów), decyzja kierownictwa urzędu (20\% urzędów) oraz inne powody (19\% urzędów).

Według opublikowanego w 2016 r. raportu Najwyższej Izby Kontroli (NIK) platformy usług publicznych, jakie funkcjonują w urzędach w Polsce, charakteryzują się bardzo znikomym wykorzystaniem. Odsetek osób posiadających profil zaufany jest niewielki. Według ówczesnego raportu NIK było to nieco ponad 1\%. Kontrola wykazała, że platforma ePUAP służyła przede wszystkim do wymiany informacji pomiędzy urzędami, a w niewielkim stopniu do świadczenia e-usług dla obywateli (Najwyższa, 2016). 
Istotnym narzędziem w procesie informatyzacji jest rozwój metod uwierzytelniania i potwierdzania tożsamości obywateli w kontaktach $\mathrm{z}$ administracją publiczną. W Polsce metody uwierzytelniania rozwinęły się w kierunku utworzenia tzw. profilu zaufanego, stanowiącego bezpłatne narzędzie, dzięki któremu obywatele mogą potwierdzać swoją tożsamość w internecie przy realizacji usług publicznych. Profil zaufany służy jako elektroniczny podpis (Ministerstwo Cyfryzacji, 2018b). Obecnie obowiązuje w tym zakresie Rozporzadzenie Ministra Cyfryzacji z dnia 10 września 2018 r. w sprawie profilu zaufanego i podpisu zaufanego (Dz.U. 2018, poz. 1760).

Całość usług publicznych jest realizowana poprzez ogólnopolską platformę ePUAP. Stanowi ona narzędzie teleinformatyczne wykorzystywane do komunikacji obywateli i przedsiębiorców z jednostkami administracji publicznej w ujednolicony, standardowy sposób. Służy również do komunikacji pomiędzy jednostkami administracji publicznej (zob. art. 16. 1a, art. 19a 1. Ustawy z dnia 17 lutego 2005 r. o informatyzacji działalności podmiotów realizujących zadania publiczne, Dz.U. 2005, nr 64, poz. 565).

\section{Rozwój systemu EZD}

Polska administracja publiczna przeprowadziła wdrożenie systemu EZD zgodnie $\mathrm{z}$ wymogami prawnymi zawartymi $\mathrm{w}$ instrukcji kancelaryjnej z 2011 r. (Rozporządzenie, 2011). Jednakże ze względu na dużą różnorodność systemów różnych urzędów i brak współpracy między nimi obecnie projektuje się system EZD RP jako ogólnopolski system elektronicznego zarządzania dokumentacją $\mathrm{w}$ administracji publicznej. Projekt wchodzi w skład działań przewidzianych w Programie Zintegrowanej Informatyzacji Państwa (Ministerstwo Cyfryzacji, 2016, s. 23), wśród których wymienia się:

- rozbudowę Systemu Rejestrów Państwowych;

- budowę eID ${ }^{5}$ jako systemu identyfikacji i uwierzytelniania obywateli;

- budowę jednolitego systemu elektronicznego zarządzania dokumentacją w administracji rządowej (EZD RP);

- zapewnienie Wspólnej Infrastruktury Państwa;

${ }^{5}$ eID to koncepcja użytkowania elektronicznego dowodu osobistego, który w sposób jednoznaczny i niezaprzeczalny potwierdza tożsamość obywatela i służy do uwierzytelnienia w e-usługach administracji publicznej oraz do podpisywania dokumentów w cyfrowym świecie. 
- dostęp do informacji o działaniach administracji i rejestrów państwowych;

- możliwość korzystania z pełnej oferty usług publicznych za pośrednictwem jednolitej bramy informacyjno-usługowej administracji poprzez Portal Rzeczypospolitej Polskiej.

W programach rządowych ważną rolę przypisuje się cyfryzacji administracji publicznej. Ministerstwo Cyfryzacji dąży do informatyzacji usług publicznych. W tym celu przyjęty został standard elektronicznego obiegu dokumentów w administracji. Według deklaracji rządowych budowa, rozwój i utrzymanie jednolitego systemu klasy EZD, stosowanego powszechnie w administracji rządowej RP, jako fundamentu sprawnej e-administracji, to jeden $\mathrm{z}$ filarów działań Ministra Cyfryzacji. Założenia dla projektu EZD RP powstały w roku 2016. Ma on na celu ustanowienie jednolitego systemu elektronicznego zarządzania dokumentacją w administracji rządowej oraz standardu systemów klasy EZD w administracji publicznej RP. W Programie Zintegrowanej Informatyzacji Państwa brano pod uwagę kluczowe znaczenie systemów EZD jako naturalnego integratora systemów teleinformatycznych wykorzystywanych przez urzędników w codziennej pracy oraz cyfryzacji procesów administracyjnych. Zwrócono uwagę na fakt, że projekt EZD RP powinien stanowić podstawę wszelkich działań związanych z usprawnianiem polskiej administracji, wprowadzając transparentność i otwartość w polskich urzędach (Ministerstwo Cyfryzacji, 2016, s. 41).

Realizacja projektu EZD RP ma polegać na fuzji dotychczasowego przedsięwzięcia Wojewody Podlaskiego - który na bazie darmowego systemu EZD PUW stworzył sieć współpracujących ze sobą urzędów rządowych, samorządowych oraz uczelni wyższych $-\mathrm{z}$ działaniami Centralnego Ośrodka Informatyki (dalej: COI). System teleinformatyczny do obsługi EZD, stworzony przez COI, stanowił eDOK. Ministerstwo Cyfryzacji uznało, że włączenie COI i Zespołu Wojewody Podlaskiego w przedsięwzięcie EZD RP uwolni potencjał i pozwoli stworzyć jednolity system teleinformatyczny, będący podstawą funkcjonowania polskiej administracji. Charakter niekomercyjny systemu EZD RP ma być gwarancją jego rozpowszechnienia jako własności Skarbu Państwa, a także jego utrzymywania i rozwijania na rzecz podmiotów realizujących zadania publiczne. Dysponentem odpowiedzialnym za finansowanie $\mathrm{z}$ budżetu państwa, bezpieczeństwo i stały rozwój systemu jest Minister Cyfryzacji. Przedsięwzięcie prowadzone jest w oparciu o wartości i filozofię współpracy jednostek administracji publicznej, wypracowaną w trakcie przedsięwzięcia Wojewody Podlaskiego (Ministerstwo Cyfryzacji, 2018a). 
Projektowanie systemu EZD RP powstaje w efekcie współpracy partnerów na wszystkich etapach jego wdrażania i utrzymania. Współpraca zakłada także dostosowanie systemu do specyfiki pracy partnerów. Jednym z etapów wdrożenia projektu będzie migracja danych z dotychczasowych systemów, m.in. EZD PUW (Elektroniczne Zarządzanie Dokumentacją Podlaskiego Urzędu Wojewódzkiego) i eDOK do EZD RP. Architektura Informacyjna Państwa zakłada, że w rozwoju systemu EZD RP istotna jest warstwa integracyjna na czterech poziomach:

- udostępniania dokumentów i informacji publicznej w postaci elektronicznej, gromadzonych w systemach EZD w sposób zautomatyzowany (udostępnianie poprzez Portal Rzeczypospolitej Polskiej), z możliwością przetwarzania udostępnianych danych przez systemy zewnętrzne;

- w obszarze Architektury Informacyjnej Państwa;

- dostępu do zasobów informacyjnych państwa (rejestrów) w sposób bezpieczny i możliwy do rozliczenia, celem upraszczania procedur administracyjnych i spraw prowadzonych w systemach EZD;

- systemów dziedzinowych urzędów, które mają zostać zintegrowane poprzez EZD RP, w myśl realizacji zasady, że w urzędzie jest jeden rejestr pism wpływających.

Partnerzy uczestniczący w projekcie będą mogli uzyskać dodatkowe moduły w systemie EZD RP poprzez uruchomienie własnych zasobów albo poprzez firmy komercyjne.

Kody źródłowe EZD RP mają zostać udostępnione, aby do rozwoju systemu włączyło się wiele instytucji, przedsiębiorców, osób fizycznych, tworząc dodatkową otwartą ścieżkę (open-source) rozwoju EZD RP. Współpraca w modelu open-source to możliwość zbudowania fundamentu dla polskiej e-administracji. Taki sposób postępowania daje szansę na rozbudowę systemu $\mathrm{w}$ kierunku realizacji szeregu zadań publicznych (Ministerstwo Cyfryzacji, 2018a).

Architektura EZD RP projektowana jest jako model SaaS, czyli Software as a Service. Architektura usługowa ma zapewnić dostępność systemu i możliwość jego wdrożenia oraz migracji pomiędzy urzędami. Zakładano, że projekt będzie udostępniony w 2018 r. w architekturze usługowej do wykorzystywania bez inwestowania przez urzędy w infrastrukturę serwerową. Utrzymanie i udostępnienie systemu powierzono COI w formie zadania zleconego przez Ministerstwo Cyfryzacji. Zakłada się także referencyjność EZD RP dla innych systemów klasy EZD. Narzędzia EZD zostaną na tyle ujednolicone, aby sprostać potrzebom poszczególnych urzędów i umożliwiać realizację procesów administracyjnych. Taki rozwój systemu EZD ma wpłynąć na wdrażanie nowo- 
czesnych założeń społeczeństwa informacyjnego i gospodarki opartej na wiedzy. Równocześnie ma umożliwić realizację indywidualnych potrzeb i zadań urzędów. Procesowość polega na realizacji usług administracji publicznej w sposób uwzględniający logiczne ciągi powtarzalnych czynności, prowadzące do osiągnięcia konkretnego rezultatu. Skuteczność zarządzania procesami w konsekwencji zapewnia wysoką jakość świadczonych usług.

\section{Archiwizacja dokumentów w systemie EZD}

Archiwizacja dokumentów uzależniona jest od struktury procesów archiwotwórczych. Bohdan Ryszewski wskazał na tę strukturę i badał ją poprzez sam zespół archiwalny. Twórca zespołu realizuje określone funkcje i działa w określonej strukturze organizacyjnej (Ryszewski, 1985, s. 86; Ryszewski, 1969, s. 104). Działalność twórcy jest możliwa dzięki prowadzeniu określonego obiegu informacji. Obieg informacji determinuje formę i zawartość powstającej dokumentacji. Dokumenty występują w określonej relacji, wynikającej z ustalonego obiegu informacji. Relacje te wyznaczają miejsce dokumentu w układzie kancelaryjnym, który w całym urzędzie dawniej nazywany był registraturą. W skład registratury wchodziły dokumenty, ale też pomoce kancelaryjne stanowiące narzędzie ewidencjonowania i zapisywania informacji o dokumencie. Współczesne tendencje w biurowości wskazują na skrócenie ścieżek obiegu informacji i ich przepływu. Nowoczesne technologie informacyjno-komunikacyjne sprawiają, że dotarcie do informacji, ich wyszukiwanie i przetwarzanie jest bardzo szybkie. Usprawniony został także przepływ informacji pomiędzy poszczególnymi szczeblami zarządzania, a także pomiędzy pracownikami wykonującymi czynności służbowe i wytwarzającymi dokumenty. Coraz częściej bezpośrednie kontakty osobiste zastępuje wymiana poczty elektronicznej (Ryszewski, 1985, s. 86; Ryszewski, 1969, s. 104).

Informatyzacja w procesie aktotwórczym dotyczy przede wszystkim kancelarii. Jest to proces, który polega na wprowadzaniu nowoczesnych metod i narzędzi informacyjno-komunikacyjnych do pracy kancelaryjnej. Informatyzacja związana jest także $\mathrm{z}$ wprowadzaniem zmian $\mathrm{w}$ zakresie funkcjonowania organizacji $\mathrm{w}$ jej sferze wewnętrznej oraz na zewnątrz. W wyniku wdrożenia zmian w administracji publicznej we wszelkich kontaktach wewnątrz organizacji oraz na zewnątrz odbywa się elektroniczne przetwarzanie danych, informacji i dokumentów. Akcentuje się zwłaszcza konieczne zmiany wewnątrz organizacji. Dopiero 
po osiągnięciu odpowiedniego poziomu informatyzacji w zarządzaniu informacją wewnętrzną i komunikacją wewnętrzną można przystąpić do informatyzacji na zewnątrz. Agnieszka Gryszczyńska we wstępie do publikacji Nowa Ksiega Wieczysta. Informatyzacja rejestru publicznego wskazała, że informatyzacja jest metodą zwiększania efektywności przetwarzania danych (Gryszczyńska, 2011). W procesie informatyzacji rośnie znaczenie powiązań między zasobami, wzajemna wymiana i weryfikacja spójności danych, norm i reguł referencyjności i interoperacyjności, ponadto prowadzi się dobór odpowiednich rozwiązań organizacyjno-technicznych.

Jednym z bardziej znaczących efektów informatyzacji dotyczących selekcji i wartościowania dokumentacji jest wprowadzenie nowego modelu publicznych zasobów informacyjnych. W wyniku wdrożenia tego modelu powstaje infrastruktura informacyjna państwa. Forma i postać publicznych zasobów informacyjnych stanowią wyzwanie na gruncie wartościowania i selekcji dokumentacji historycznej. Pojęcie publicznych zasobów informacyjnych nie jest tożsame z narodowym zasobem archiwalnym. Nie sposób zdecydować odgórnie, czy publiczny zasób informacyjny stanowią materiały archiwalne godne wieczystego przechowywania $\mathrm{w}$ archiwach. Zasób ten może być traktowany jako forma prezentacji dokumentów, jest to jakościowo nowa forma dokumentacji bieżącej (Gryszczyńska, 2011, s. 13).

Zgodnie z Ustawa z dnia 14 lipca 1983 r. o narodowym zasobie archiwalnym $i$ archiwach (Dz. U. 1983, nr 38, poz. 173) narodowy zasób archiwalny powinien służyć: nauce, kulturze, gospodarce narodowej i potrzebom obywateli (art. 2 ust. 1). Materiały archiwalne określone w art. 1 ww. ustawy stanowią dokumentację, bez względu na formę kancelaryjną i sposób jej wytwarzania, mającą znaczenie jako źródło informacji o wartości historycznej, czyli o działalności państwa polskiego, poszczególnych organów państwowych, innych jednostek organizacyjnych, o stosunkach państwa polskiego z innymi państwami, o rozwoju życia społecznego i gospodarczego, o działalności organizacji o charakterze politycznym, społecznym i gospodarczym, zawodowym i wyznaniowym, o organizacji oraz rozwoju nauki, kultury i sztuki. Według ustawy aktotwórcy mają obowiązek przekazywania dokumentacji stanowiącej materiały archiwalne do właściwego archiwum państwowego, pozostała dokumentacja może ulec brakowaniu, zgodnie $\mathrm{z}$ art. 5 ust. 1.

Specyfika dokumentu elektronicznego polega na tym, że składa się na niego tekst elektroniczny i informacje oraz dane $\mathrm{w}$ formie elektronicznej, które opisują kontekst powstania i istnienia dokumentu 
elektronicznego w systemie. Odwzorowanie cyfrowe, jakie ma miejsce w systemie EZD, sprawia, że dokument elektroniczny nie jest oryginałem. Stąd też niejednokrotnie nie uznaje się jego formy elektronicznej w obrocie prawnym.

\section{Zakończenie}

EZD RP stanowi nową perspektywę dla informatyzacji nadzoru nad narastającym zasobem archiwalnym oraz stwarza nowe możliwości w zakresie archiwizacji dokumentów. System ten nie jest jednak pozbawiony problemów wynikających $\mathrm{z}$ próby stosowania zaawansowanych technologii informacyjnych do automatyzacji nadzoru oraz do kontroli jakości informacji archiwalnej, zarówno na poziomie warstwy semantycznej i syntaktycznej, jak i na poziomie prezentacji tej informacji. Następuje przeformułowanie archiwalnego paradygmatu zachowania dokumentacji. Dąży się do zachowania informacji i danych, wreszcie do archiwizacji wiedzy.

Istotne zagadnienia wymagające dalszych badań to: konsekwencje decentralizacji czynności kancelaryjnych, nowe zasady przekazywania dokumentacji elektronicznej do Narodowego Archiwum Cyfrowego oraz centralizacja archiwizacji elektronicznych dokumentów.

Konieczne jest odejście od postępowania $\mathrm{z}$ dokumentacją w sposób uwzględniający prowadzenie sprawy w kierunku postępowania zakładającego myślenie transakcyjne. Dokumentowanie spraw uwzględnia wówczas tworzenie rekordów, baz danych, które są konsekwencją podejmowanych decyzji.

Zidentyfikowane problemy skutkują koniecznością zmian organizacyjnych $\mathrm{w}$ ramach procesów nadzoru nad narastającym zasobem archiwalnym. Przeprowadzenie tych zmian wiąże się z decyzją o reorganizacji, co z kolei wymaga należytego uzasadnienia, wskazania celów i przygotowania oraz wdrożenia odpowiednich etapów postępowania.

Problem, jaki został tu naświetlony, oraz jego skutki i przyczyny nie pozostawiają wątpliwości, że właściwy kierunek zmian to przeprowadzenie informatyzacji nadzoru. Celem planowanych zmian jest dostosowanie obecnego nadzoru do poziomu rozwoju informatyzacji w kraju, a także do poziomu informatyzacji, jaki urzędy prowadzą w swojej wewnętrznej pracy. 


\section{Literatura}

Gryszczyńska, A. (2011). Nowa Księga Wieczysta, informatyzacja rejestru publicznego. Warszawa: LexisNexis.

Maciejewska, W. (red.) (1974). Polski stownik archiwalny. Warszawa: Naczelna Dyrekcja Archiwów Państwowych.

Ministerstwo Cyfryzacji (2014). Wpływ cyfryzacji na działanie urzędów administracji publicznej w Polsce w 2014 roku. Pobrane z: https://www. gov.pl/documents/31305/0/wplyw_cyfryzacji_2014_wersja_zaadaptowana. pdf/1ae462ab-b74a-a9c1-5772-dae95a40c741 (28.01.2019).

Ministerstwo Cyfryzacji (2016). Program Zintegrowanej Informatyzacji Państwa. Pobrane z: https://www.gov.pl/documents/31305/0/PZIP+wrzesie\%C5\%84+ 2016+r..pdf/9be4a5fe-2395-8904-5dbc-73e46deb284a (28.01.2019).

Ministerstwo Cyfryzacji (2018a). EZD RP - elektroniczne zarządzane dokumentacją w administracji publicznej RP. Wspólny projekt NASK i Wojewody Podlaskiego. Pobrane z: https://ezd.gov.pl/assets/ezdrp/Warsztaty\%20 EZD\%20RP\%20-\%2023\%20kwietnia\%202018.pdfv (28.01.2019).

Ministerstwo Cyfryzacji (2018b). Obywatel.gov.pl. Pobrane z: https://obywatel. gov.pl/zaloz-profil-zaufany (28.01.2019).

Najwyższa Izba Kontroli (2016). NIK o ustugach elektronicznych $w$ administracji publicznej.Pobrane z: https://www.nik.gov.pl/aktualnosci/niko-uslugach-elektronicznych-w-administracji-publicznej.html (28.01.2019).

Robótka, H. (2010). Wspótczesna biurowość, zagadnienia ogólne. Toruń: Wydawnictwo Naukowe Uniwersytetu Mikołaja Kopernika.

Rozporządzenie Ministra Cyfryzacji z dnia 10 września 2018 r. w sprawie profilu zaufanego i podpisu zaufanego (2018). Dziennik Ustaw Rzeczypospolitej Polskiej, poz. 1760.

Rozporządzenie Prezesa Rady Ministrów z dnia 18 stycznia 2011 r. w sprawie instrukcji kancelaryjnej, jednolitych rzeczowych wykazów akt oraz instrukcji w sprawie organizacji i zakresu działania archiwów zakładowych (2011). Dziennik Ustaw Rzeczypospolitej Polskiej, 14, poz. 67.

Ryszewski, B. (1969). O niektórych podstawowych pojęciach archiwalnych. Zeszyty Naukowe UMK. Historia t. 5, s. 93-120.

Ryszewski, B. (1985). Problemy i metody badawcze archiwistyki. Toruń: Wydawnictwo Naukowe Uniwersytetu Mikołaja Kopernika.

Ustawa z dnia 14 lipca 1983 r. o narodowym zasobie archiwalnym i archiwach (1983). Dziennik Ustaw Rzeczypospolitej Polskiej, 38, poz. 173. Ustawa z dnia 17 lutego 2005 r. o informatyzacji działalności podmiotów realizujących zadania publiczne (2005). Dziennik Ustaw Rzeczypospolitej Polskiej, 64, poz. 565.

Tekst $w$ wersji poprawionej wptynąt do redakcji 24 marca $2019 r$. 


\title{
Justyna Adamus-Kowalska
}

Department of Information Management

The Institute of Library Science and Scientific Information

University of Silesia in Katowice

e-mail: justyna.adamus@us.edu.pl

(D) https://orcid.org/0000-0002-8245-7631

\section{Polish state policy in the field of handling electronic documentation and implementation of electronic documentation management system (EZD) in the context of computerization}

\begin{abstract}
Managing electronic documentation is one of the most important tasks of modern public administration. The article points out the need to apply legal regulations in the field of computerization and office instruction, determining the way of maintaining official documentation in public entities. The ICT tools described in the article in the form of the EZD system are intended to demonstrate how the national archival resource is currently shaped. In order to improve the process of computerization of public administration, government programs are adopted, e.g. the Integrated State Computerization Program discussed in the article. The presented research proves that for the full implementation of electronic public administration services it is necessary to unify the principles governing the functioning of the office system, including the adoption of appropriate assumptions and implementation of the EZD RP system and wider use of the nationwide platform for communication with public administration (ePUAP).
\end{abstract}

Keywords: Administration. Administrative office. Computerisation. Electronic document. EZD system 
